\title{
Impact of Informal Auto-Mobile Mechanic Workshops Activities on Groundwater Quality in Ibadan, Nigeria
}

\author{
Elizabeth 0. Oloruntoba*, Toluwanimi 0. Ogunbunmi \\ Department of Environmental Health Sciences, Faculty of Public Health, College of Medicine, University of Ibadan, Ibadan, Nigeria \\ Email: *li_zzyy@yahoo.com
}

How to cite this paper: Oloruntoba, E.O. and Ogunbunmi, T.O. (2020) Impact of Informal Auto-Mobile Mechanic Workshops Activities on Groundwater Quality in Ibadan, Nigeria. Journal of Water Resource and Protection, 12, 590-606.

https://doi.org/10.4236/jwarp.2020.127036

Received: June 2, 2020

Accepted: July 20, 2020

Published: July 23, 2020

Copyright ( 2020 by author(s) and Scientific Research Publishing Inc. This work is licensed under the Creative Commons Attribution International License (CC BY 4.0).

http://creativecommons.org/licenses/by/4.0/

\begin{abstract}
The detrimental effect of the activities in informal auto-mobile mechanic workshops is a major public health concern; and its impact on groundwater contamination cannot be ignored. We assessed the effect of activities of mechanics in auto-mobile workshops on the quality of groundwater sources. Water samples were collected from hand dug wells situated within 0 to 50 metres in twenty auto-mobile workshops randomly selected across three zones. A residential area was selected as the control site. Analysis of water for some physico-chemical parameters ( $\mathrm{pH}, \mathrm{TDS}$, Electrical Conductivity, Alkalinity, Oil and Grease) and the heavy metals $(\mathrm{Cu}, \mathrm{Cd}, \mathrm{Cr}$, and $\mathrm{Pb})$ was done using standard methods. Sanitary inspection was also carried out at each well location. Results were compared with the control and regulatory standards Nigerian Industrial Standard for Drinking Water Quality (NISDQW) and World Health Organization (WHO) guidelines for drinking water quality. Results revealed that mean values of $\mathrm{pH}$, TDS and Electrical conductivity for the three zones, Alphonso, Temidire, and Ojoo were within WHO limits. The concentrations of $\mathrm{Cu}, \mathrm{Cd} \mathrm{Cr}$ and $\mathrm{Pb}$ in the water samples ranged from $0.02-6.12 \mathrm{mg} / \mathrm{l}, 0.1$ $2.19 \mathrm{mg} / \mathrm{l}, 0.2-0.79 \mathrm{mg} / \mathrm{l}$ and $0.02-35.8 \mathrm{mg} / \mathrm{l}$ across the three zones respectively. Mean concentrations of $\mathrm{Cu}(\mathrm{mg} / \mathrm{l})$ were significantly higher in Alphonso $(2.5 \pm 2.06)$ than in other zones. Mean concentration of $\mathrm{Cr}(\mathrm{mg} / \mathrm{l})$ was $0.34 \pm$ $0.28,0.37 \pm 0.13$ and $0.31 \pm 0.3$ for Alphonso, Temidire and Ojoo respectively. Cadmium was also present in all the zones but $\mathrm{Pb}$ was only detected in $\mathrm{Al}-$ phonso. The mean concentrations for heavy metals were significantly higher when compared with the permissible limits for both NISDQW and WHO. The degree of groundwater contamination indicates poor water quality in the study area, and this requires regular monitoring. Enforcement of environmental regulations guiding activities of auto-mechanics should be done so that they can embrace environmentally friendly practices to reduce pollution.
\end{abstract}




\section{Keywords}

Auto-Mobile Workshops, Contamination, Heavy Metals, Groundwater

\section{Introduction}

In Nigeria, the aftermaths of the devaluation of the currency led to importation of used vehicles, known as "Tokunbo". Ever since, the number of vehicles imported into the country increased annually as it became cheaper to buy the used vehicles. However, this has been at a cost to the environment as they were found to pollute the air with emissions of incomplete combustion of the old engines such as Carbon oxides (COx), Nitrogen oxides (NOx), Sulphur oxides (SOx), etc. [1].

The rapid importation and influx of "fairly used" vehicles have caused a proliferation of many auto-mobile mechanic workshops all over the country. Many vacant plots and farmlands have been converted to workshops by auto-mechanics and other specialized individuals who engage in auto repair [2]. Activities carried out in the auto-mobile workshops include: general servicing (engine and air condition servicing)-cleaning and washing engine parts, welding, panel beating, painting and body spraying, electrical repair, vulcanizing and battery charging [3].

Groundwater can be found almost everywhere. It accounts for about two-thirds of the freshwater resources of the world and more than $98 \%$ of the global quantity of available freshwater is groundwater stored in pores and fractures of rock strata [4] [5]. Groundwater is an important resource which can act as a natural storage that can buffer against shortage of surface water during times of drought. It is replenished through a natural process by surface water from precipitation, streams, and rivers, as well as by rain and snow melt. Over the years, industrialization and urbanization have progressed steadily with little consideration for environmental consequences, thus resulting in groundwater pollution [6]. Groundwater pollution arises majorly as a result of anthropogenic activities such as: accidental spills from petroleum and its related industries, agricultural activities, mining, acid rain, poor construction and maintenance of waste disposal system (private sewage disposal systems, land disposal of solid waste) and municipal wastewater. One of such activities is carried out in auto-mobile workshops. Automobile is a major means of transport through which people and goods are moved from one place to another and as long as they remain on our roads, there will always be a need for them to be serviced time and again to deliver effective result.

Several studies conducted on auto-mobile mechanic workshops in Nigeria have reported heavy metals (copper, lead, chromium, cadmium and zinc), hydrocarbons (oil and grease, volatile organic compounds (VOCs), poly-aromatic hydrocarbons (PAHs)) and toxic chemicals (solvents, chlorinated compounds, glycols) as major pollutants of groundwater around these workshops [3] [7] [8] [9] [10]. 
These contaminants which can persist in the environment over a long period of time have been linked to various types of organ damage, cancers, developmental or growth problems and death of plants, animals and humans [11].

Over the years the steady increase of heavy metals into the environment has been a major concern. As trace elements, some of the heavy metals are useful for body metabolism (e.g. zinc and copper) but in higher concentrations they can be toxic [12] while others are toxic even in very low concentrations (e.g. Lead, Cadmium and Mercury). Heavy metals are dangerous because they tend to bioaccumulate and finally pose serious health hazards to human beings and animals [13]. Exposure to these heavy metals such as chromium (VI) has been observed to cause damage to liver, kidney circulatory organs and nerve tissues, wheezing and shortness of breath and immune system weakness. According to IARC [14], it is a human carcinogen. Lead $(\mathrm{Pb})$ is another major environmental pollutant which has been observed to affect the nervous system, reproductive system, and immune system [15].

Groundwater is one of the most important available sources of water in many areas in Nigeria and many communities depend on hand-dug wells for domestic use because of their accessibility and affordability. It is therefore imperative that groundwater sources in these communities should be prevented from being polluted with contaminants that have the capacity to remain in the environment over a long period of time and pose serious health problems. Although some studies have been done on auto-mobile mechanic villages in Nigeria, limited information has been given on small clusters of auto-mobile workshops scattered around residential areas with poor regulatory provisions and the impact of their activities on the quality of groundwater used for domestic purposes in these communities. This study was therefore designed to assess the effect of informal auto-mobile mechanic workshops activities on groundwater quality in some parts of Akinyele local government area, Ibadan, Oyo State.

\section{Materials and Methods}

\subsection{Study Area}

The study area for this research was Akinyele Local Government Area (ALGA) in Oyo State with its headquarters at Moniya (Figure 1). It lies between latitude $7^{\circ} 29^{\prime}$ to $7^{\circ} 40^{\prime}$ while its longitude ranges from $3^{\circ} 45^{\prime}$ to $4^{\circ} 04^{\prime}$. It occupies a land area of 464.892 square kilometers with a population density of 516 persons per square kilometer. This area covers Akingbile, Alphonso, Ojoo, Abata kan, Oba Temidire which are typically residential areas with some petty trading and small-scale businesses around. Also, located here is the International Institute of Tropical Agriculture (IITA) and the Military Barracks (Ojoo Cantonment). The area is divided by the Old Oyo inter-state road. The Ojoo-Alphonso axis serves as a transit point for many travelers travelling from the Northern part of the country down south and vice versa. As a result of this, a number of auto-mobile mechanic workshops are seen scattered along the roadsides to provide services to auto-mobiles owners. 


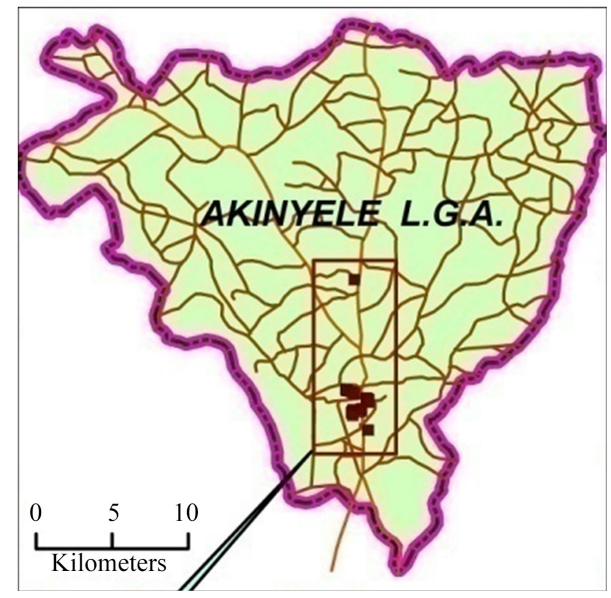

Figure 1. Map of study area. Source: Geography Department, University of Ibadan.

Being majorly residential, a few hand-dug wells were seen around, many of which were without recommended sanitary features (e.g. apron and drainage). Some of these wells were covered with planks, metal lids or aluminum sheets. The topography of the place was sloppy with some rocky areas. Some other structures around there are mosques, food canteen and primary schools.

\subsection{Site Selection}

The study sites were selected using multistage random sampling technique. First Ibadan metropolis consists of 11 local government areas (5 urban and 6 rural). The rural LGAs were purposively selected because they have easy access to undeveloped plots of land. The study LGA, Akinyele, was randomly selected from the six LGAs using a lottery method (each member of the LGA was assigned a number, after which one number was selected at random).

The auto-mobile mechanic workshops in the study were divided into six zones, lottery method was used to randomly select three zones (Alphonso, Temidire and Ojoo). Alphonso zone represented workshops within Alphonso area. Temidire zone represented workshops along Barracks and Temidire area and Ojoo zone represented workshops under Ojoo unit 1.

Eight auto-mobile mechanic workshops were selected from each zone using criteria such as: number of years of operation ( 5 years), absence of other industries within the area, presence of groundwater and type of activities carried out within the workshop. The control site (Moniya) was randomly selected from the remaining three zones. The residential area picked from this zone was based on absence of industrial, auto-mobile and transporting activities, and the presence of undisturbed vegetation and groundwater. It is important to state that the hydrogeological and geological setting in the study and control zones were similar. A numerical simulation of underground flow in the aquifer in Akinyele Local Government Area by Ajibola et al., [16] idealised Akinyele domain as fractured basement rocks and weathered basement rocks aquifer. 


\subsection{Water Sample Collection and Analysis}

This paper represents part of a larger study that assessed the levels of physico-chemical parameters, organic compounds such as Benzene, Toluene, Ethyl benzene, Xylene (BTEX) and Oil \& grease in soil and groundwater around informal auto-mobile mechanic workshops; sanitary status of groundwater sources and the attitudes of mechanic operators. The scope of this paper does not cover soil and BTEX analysis in both water and soil.

Water samples were collected from dug wells within zero (0) to 50 metres of each workshop using the standard water sampling procedures by APHA [17]. Replicate samples were collected in 1 litre plastic bottles. As part of the quality control measures, distilled water was used as the sample blank. The samples were then transported to the laboratory for further analyses. Physico-chemical analyses were carried out on each of the samples. Conventional variables were measured as indicators to establish a general picture of the aquatic environment, including the influences of the drainage basin and local environmental conditions around the auto-mobile mechanic workshops. The variables include: $\mathrm{pH}$, Electrical conductivity (EC), Total dissolved solids (TDS) and heavy metals. The $\mathrm{pH}$ was measured using a Technel and Technel USHA table $\mathrm{pH}$ meter model PHS-25 while the EC and TDS were measured using a Jenwey combined TDS/Conductivity meter model 470 . Samples were also analyzed for total alkalinity, and oil and grease using standard methods by APHA [17]. The concentrations of heavy metals such as cadmium, chromium, copper and lead in water samples were analysed by flame atomic absorption spectroscopy (FAAS). The quality of the sampled groundwater sources around the mechanic workshops was evaluated by comparing with control site, World Health Organization guidelines for drinking water quality [18] and Nigerian Industrial Standard for Drinking Water Quality (NISDQW) by Standards Organization of Nigeria (SON) [19].

\subsection{Sanitary Inspection of Water Sources}

Sanitary inspection was conducted at each well location to identify all the hazards that were potential and actual causes of contamination of the water sources. It provided a comprehensive knowledge of conditions at the water sources at the time of the inspection. Standard sanitary inspection forms adapted from WHO [20] was used to assess the physical structure of the wells as well as the probable sources of pollution. Twenty dug wells were inspected using an observational checklist consisting of a set of questions phrased for "Yes" or "No" answers. Every positive answer was scored one mark, while a negative answer was scored zero. Dug wells in this study were scored on a 13-point scale. The risk of contamination of each well was classified according to WHO [20] as: no risk, low, medium, high, or extremely high risk as shown below.

No risk $=0$, Low $=1-3$; Intermediate risk $=4-7$, High risk $=8-10$; Extremely high risk $=>10$. 


\section{Results and Discussion}

\subsection{Auto-Mobile Mechanic Activities}

The workshops in the study area have been in operation for 5 - 18 years of existence and they had a range of activities which include auto servicing and maintenance, battery charging and repair, panel beating, welding (arc/electric), spraying, electrical repair and painting. Activities practiced daily varied with auto servicing and maintenance $(88.4 \%)>$ panel beating $(50 \%)>$ electrical repair $(41.1 \%)$ $=$ painting $(41.1 \%)>$ welding $(33.9 \%)>$ battery repair $(25.9 \%)$.

Highest job designation among the study participants were the auto-mobile mechanics who were found at least in each workshop. This can be related to the rapid increase and spread of mechanic workshops across the town as a result of the high increase in importation of "Fairly used" vehicles. This was corroborated by Ajayi and Dosunmu [1] that estimated an increase in the importation of used motor vehicles from less than 500 in 1988 to about 30,000 in 2000. Also, the cost of servicing of vehicles by major car servicing centers has led to the springing up of these auto mechanics that are available and cheaper to approach. The length of years of existence of these workshops which from the study had ranged from 5 - 18 years had led to a level of confidence and trust in some of these operators hence, more inflow of cars for serving and repair which in turn leads to more spills of oil to the ground during the process of engine oil and change and car engine servicing [3].

We observed that the activities in the different workshops were based on skilled operators functioning in different units (Figure 2). This also informed the type and quantity of wastes generated. Some of these include engine oil waste, gear box oil waste, petrol, carbide, acid, metal scrap, nylons, wires, paints containers and thinners, car plugs and batteries (Figure 3 ). The auto servicing operators had the highest activity, with engine oil drained from vehicles constituting the largest amount of waste generated $(60.1 \%)$. The least waste generated was from the battery chargers. Figures 4-6 show different scenarios in the study locations. Our results corroborate that of Nwachukwu et al., [10] that put together a hypothetical model of the sources of occupational wastes in three auto-mobile mechanic villages in the Imo River basin.

\subsection{Physico-Chemical Quality of Water from the Wells}

\section{Appearance of samples}

The appearance of the water samples varied from colourless to slightly brown. Samples from Alphonso were generally colourless while Temidire and Ojoo had some samples that were slightly brown and visibly contaminated with dirt (Table 1).

$$
p H
$$

The $\mathrm{pH}$ values of water samples from the locations were within the same range. The $\mathrm{pH}$ values ranged between 5.1 and 7.4 across the three zones. Alphonso had a mean value of $6.4 \pm 0.8$ (5.1 - 7.4), Temidire $6.8 \pm 0.7$ (5.7 - 7.4), 


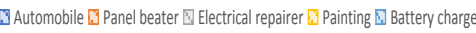

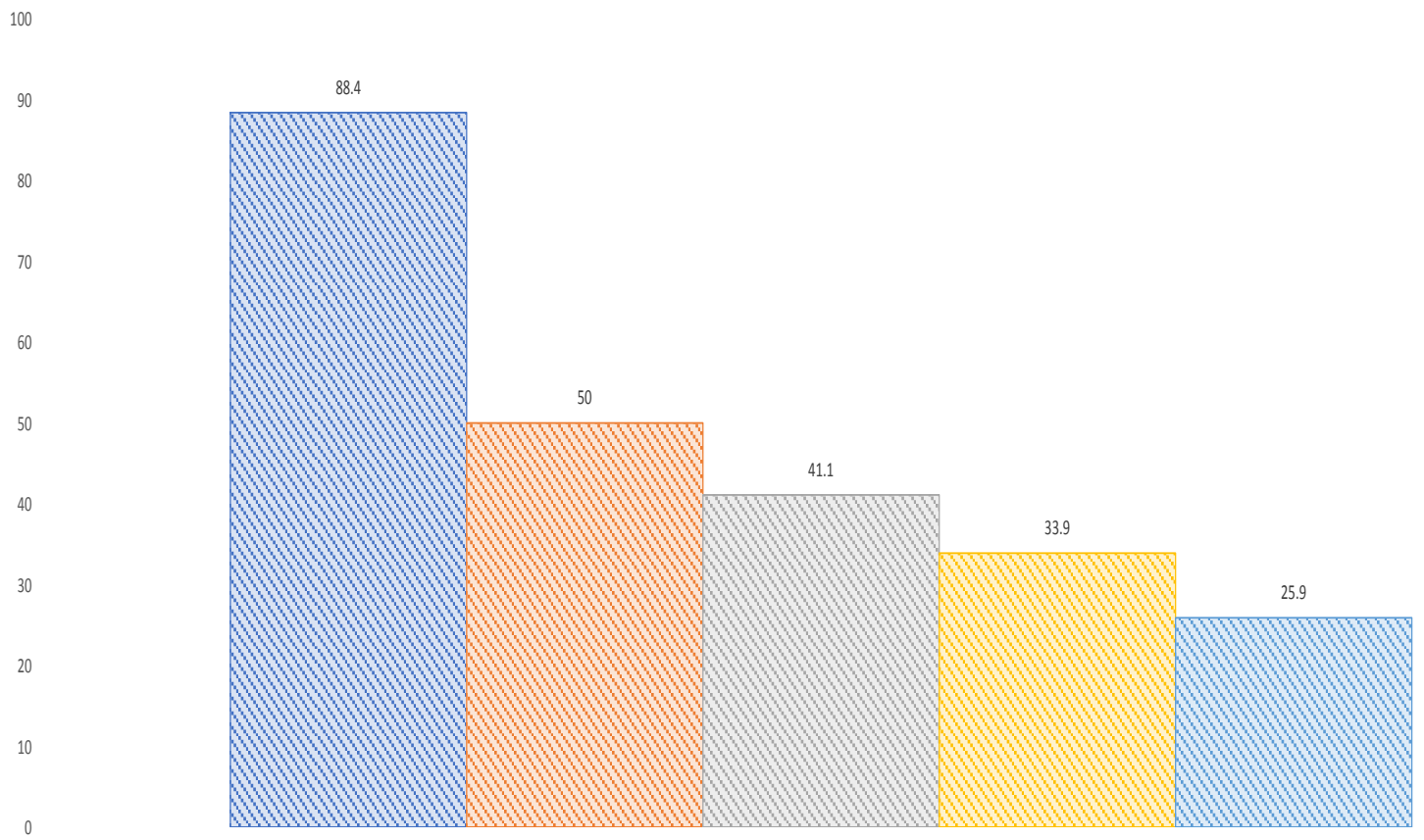

Figure 2. Speciality of artisans in the auto-mobile mechanic workshops in the study area.

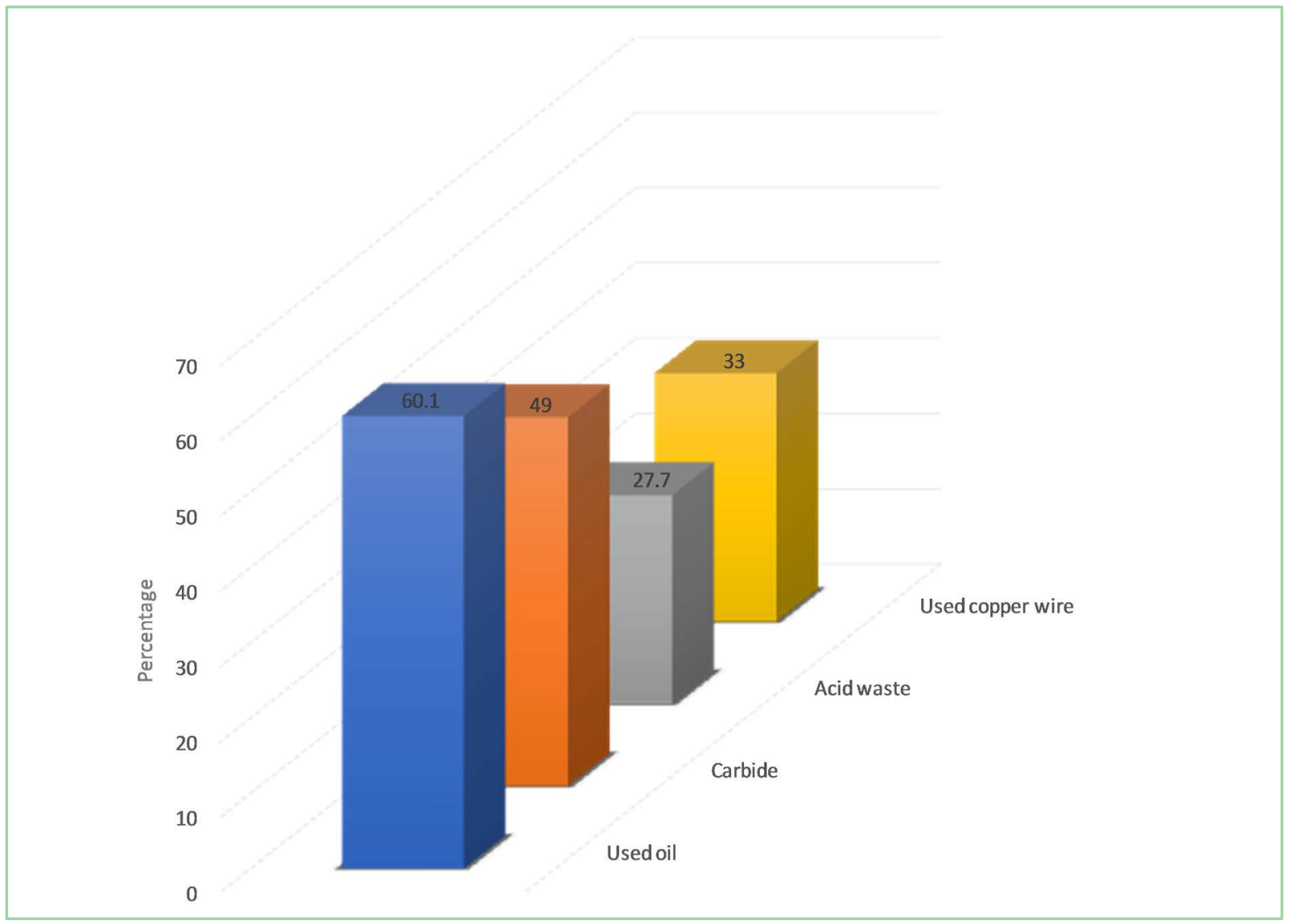

Figure 3. Types of wastes generated in the auto-mobile mechanic workshops in the study area. 


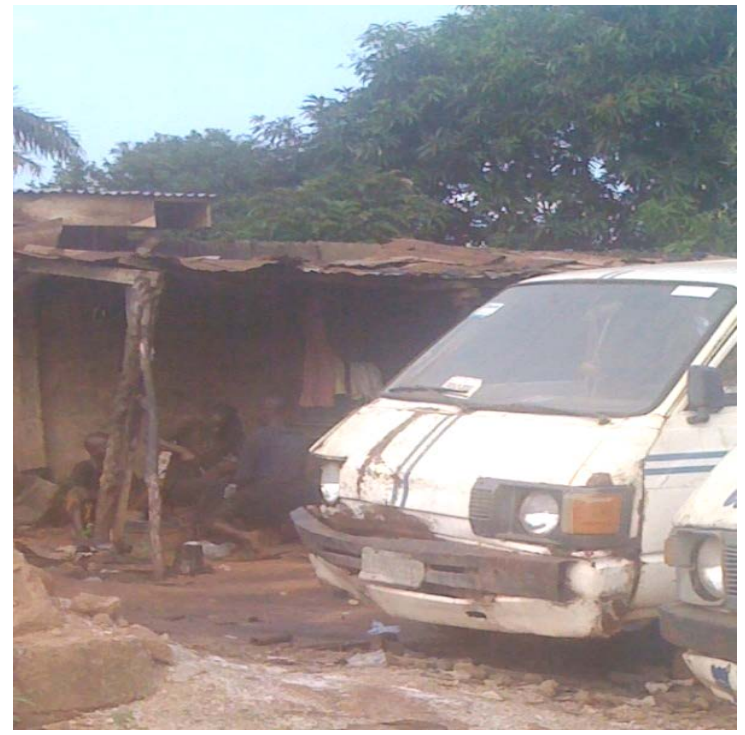

Figure 4. Vehicle repair in workshop.

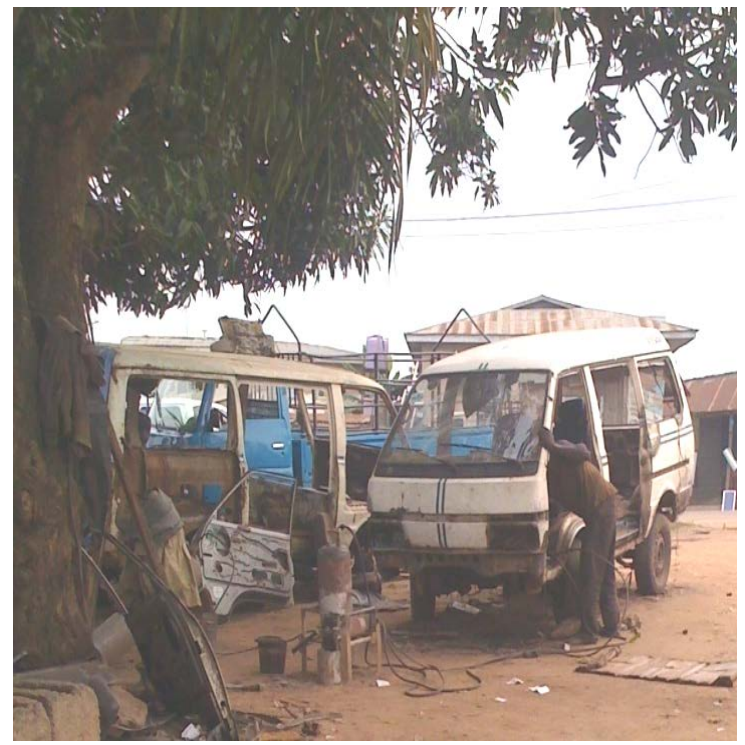

Figure 5. Panel beating activity.

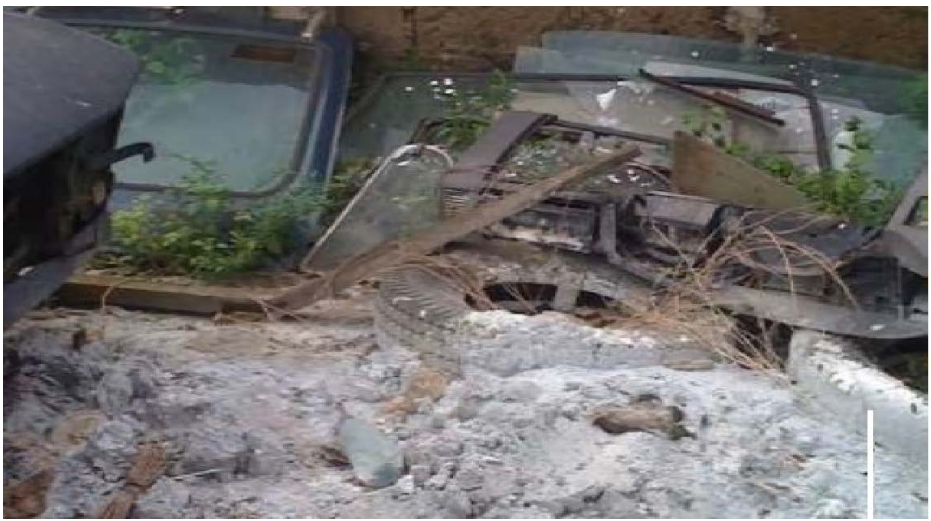

Figure 6. Carbide waste at a mechanic workshop. 
Table 1. Mean values of the physico-chemical parameters of water across the locations and regulatory limits.

\begin{tabular}{|c|c|c|c|c|c|c|}
\hline Parameters & Alphonso & Temidire & Ojo & Control & NIS (2007) & WHO 1993 \\
\hline Appearance & Colourless & Slightly brown & Slightly brown & Colourless & - & - \\
\hline $\mathrm{pH}$ & $6.4 \pm 0.8$ & $6.8 \pm 0.7$ & $6.7 \pm 0.4$ & $7.6 \pm 0.2$ & \multirow{2}{*}{$6.5-8.5$} & \multirow{2}{*}{$6.5-8.5$} \\
\hline Range & $5.1-7.4$ & $5.7-7.4$ & $6.1-7.2$ & $7.6-7.8$ & & \\
\hline Alkalinity (mg/l) & $58.3 \pm 28.6$ & $59.4 \pm 46.3$ & $99.5 \pm 82.5$ & $54.3 \pm 2.1$ & & \\
\hline Range & $36-116$ & $19-112$ & $18-260.8$ & $50.1-58.5$ & - & - \\
\hline Conductivity $\left(\mu \mathrm{SCm}^{-1}\right)$ & $94.6 \pm 28.5$ & $195.1 \pm 97.2$ & $269.2 \pm 164.6$ & $60.5 \pm 0.3$ & \multirow{2}{*}{1000} & \multirow{2}{*}{300} \\
\hline Range & $64.8-152.0$ & $120.8-363.5$ & $82.5-501.5$ & $59.9-61.1$ & & \\
\hline TDS (mg/l) & $57.8 \pm 16.4$ & $117.1 \pm 58.3$ & $152.7 \pm 85.3$ & $36.2 \pm 0.2$ & \multirow{2}{*}{500} & \multirow{2}{*}{500} \\
\hline Range & $38.8-91.4$ & $72.6-218$ & $51.7-277$ & $35.8-36.6$ & & \\
\hline Temperature $\left({ }^{\circ} \mathrm{C}\right)$ & $26.9 \pm 0.3$ & $24.3 \pm 0.5$ & $24.2 \pm 0.8$ & $27.1 \pm 1$ & \multirow{2}{*}{ Ambient } & \multirow{2}{*}{ Ambient } \\
\hline Range & $26.5-27.3$ & $23.8-25$ & $23.1-25.3$ & $25.1-29.1$ & & \\
\hline Oil \& Grease $(\mathrm{mg} / \mathrm{l})$ & $1282.9 \pm 163.8$ & $1065.6 \pm 1383.8$ & $2258 \pm 955.5$ & $58.3 \pm 0.6$ & \multirow{2}{*}{ - } & \multirow{2}{*}{$10-30$} \\
\hline Range & $1068-1560$ & $34-3174$ & $218-3024$ & $57.1-59.5$ & & \\
\hline $\mathrm{Cu}(\mathrm{mg} / \mathrm{l})$ & $2.5 \pm 2.06$ & $0.03 \pm 0.01$ & $0.03 \pm 0.01$ & $1.46 \pm 0.01$ & \multirow{2}{*}{1} & \multirow{2}{*}{1} \\
\hline Range & $0.38-6.12$ & $0.02-0.04$ & $0.01-0.05$ & $1.45-1.47$ & & \\
\hline $\mathrm{Cr}(\mathrm{mg} / \mathrm{l})$ & $0.34 \pm 0.28$ & $0.37 \pm 0.13$ & $0.31 \pm 0.3$ & \multirow{2}{*}{ ND } & \multirow{2}{*}{0.05} & \multirow{2}{*}{0.05} \\
\hline Range & $0.00-0.66$ & $0.2-0.57$ & $0.00-0.79$ & & & \\
\hline Cd (mgl) & $0.01 \pm 0.02$ & $0.37 \pm 0.51$ & $0.64 \pm 0.79$ & \multirow{2}{*}{ ND } & \multirow{2}{*}{0.003} & \multirow{2}{*}{0.003} \\
\hline Range & $0.01-0.047$ & $0.1-1.29$ & $0.04-2.19$ & & & \\
\hline $\mathrm{Pb}(\mathrm{mg} / \mathrm{l})$ & $10.5 \pm 11.37$ & \multirow{2}{*}{ ND } & \multirow{2}{*}{ ND } & \multirow{2}{*}{ ND } & \multirow{2}{*}{0.01} & \multirow{2}{*}{0.01} \\
\hline Range & $0.00-35.8$ & & & & & \\
\hline
\end{tabular}

$\mathrm{ND}=$ Not detected, NIS = National standard for drinking water quality.

Ojoo $6.7 \pm 0.4(6.1-7.2)$, while Moniya (the control site) had a mean concentration of $7.6 \pm 0.2(7.6-7.8)$. Locations in Alphonso and Temidire had $\mathrm{pH}$ values which were slightly acidic (Table 1). The results show that some of wells at Alphonso and Temidire zones had $\mathrm{pH}$ values lower than the permissible limits by World Health Organization (WHO) and Standards Organization of Nigeria (SON) for domestic use and drinking water (6.5 - 8.5). The low $\mathrm{pH}$ of some of the water sources might be as a result of the activities of the battery chargers that discharge the spent electrolyte into their surroundings. However, the mean $\mathrm{pH}$ of the control site was within permissible limit. The acidic nature of water from these locations may be attributed to possible contamination from improper disposal of battery water and cleaning solvents used in the auto-mobile mechanic workshops. These hazardous constituents percolate through the soil and contaminate the surrounding groundwater easily since all mechanic workshops visited do not have cemented floors. Studies on evaluation of groundwater quality for its suitability for drinking and agricultural purposes associated the acidic nature of the water sources with $\mathrm{pH}$ range 5.2 to 6.8 with anthropogenic activities around the area [21]. The range of the $\mathrm{pH}$ also falls into the category of slightly polluted water according to the grouping by Prati et al., [22]. There have been several reports on the effects of acidic waters on both the human health and the environment. 
DiValentino [23] revealed that acidic waters have been known to cause irritation due to corrosion effects and at extreme levels worsen existing skin conditions. It can also cause laundry staining or blue-green stains in sinks and drains. Although the $\mathrm{pH}$ has not indicated that the water from sources around these sites are alkaline, presence of spent carbide in these workshops have a capacity to cause this because they are highly alkaline and serve as a great source of acetylene gas (a volatile organic compound) when they react with water [24]. The presence of calcium carbide in large quantities has also been found to adversely affect plants and microorganisms and degrade the quality of groundwater although the toxicity decreases over a period of time.

\section{Alkalinity}

The alkalinity ranged from $18 \mathrm{mg} / \mathrm{l}$ to $260.8 \mathrm{mg} / \mathrm{l}$ across the zones. Alphonso had an average value of $58.3 \pm 28.6 \mathrm{mg} / \mathrm{l}$, Temidire $59.4 \pm 46.3 \mathrm{mg} / \mathrm{l}$ and Ojoo $99.5 \pm 82.5 \mathrm{mg} / \mathrm{l}$. The control site had the lowest mean concentration of $54.3 \pm$ $2.1 \mathrm{mg} / \mathrm{l}$. All the zones had the same trend in alkalinity. The mean electrical conductivity (EC) of samples from the zones are $94.6 \pm 28.5 \mu \mathrm{Scm}^{-1}, 195.1 \pm 97.2$ $\mu \mathrm{Scm}^{-1}, 269.2 \pm 164.6 \mu \mathrm{Scm}^{-1}$ for Alphonso, Temidire and Ojoo respectively. The control site had a mean concentration of $60.5 \pm 0.3 \mu \mathrm{Scm}^{-1}$ (Table 1). The electrical conductivity in all the zones were higher than the control. In comparison with regulatory standards, the wells in Alphonso zone had some samples with values lower than the WHO limit, while the other zones had some samples with values above the permissible limits of $300 \mu \mathrm{Scm}^{-1}$ [18], making the water source unsafe for domestic use and drinking. The taste of water could also be affected when conductivity is high [25]. Similar observations have been reported in studies carried out by Ololade et al. [26], which revealed high electrical conductivity in dug wells and other groundwater sources.

Total dissolved solids, TDS

The mean total dissolved solids (TDS) were $57.8 \pm 16.4 \mathrm{mg} / \mathrm{l}, 117.1 \pm 58.3$ $\mathrm{mg} / \mathrm{l}, 152.7 \pm 85.3 \mathrm{mg} / \mathrm{l}$ for samples from Alphonso, Temidire and Ojoo respectively. The control site had a mean concentration of $36.2 \pm 0.2 \mathrm{mg} / \mathrm{l}$. The TDS results across the zones were all higher than the control but within WHO and SON permissible limits for water quality $(500 \mathrm{mg} / \mathrm{l})$. Our results are like those reported by Alao et al., [27] which assessed the effect of brewery waste on groundwater quality, and Nebo et al., [28] that assessed impacts of mechanic workshop on soil and groundwater quality in Port Harcourt, Rivers State, Nigeria.

\section{Oil and grease}

The concentrations for oil and grease across the locations (Table 1) were remarkably high. The results show the concentration ranges from a value of $58 \mathrm{mg} / \mathrm{l}$ to $3024 \mathrm{mg} / \mathrm{l}$. This range is extremely higher than 0 to $55.6 \mathrm{mg} / \mathrm{l}$ obtained by Adewoyin et al. [29]. The mean values for the three zones were $1282.9 \pm 163.8$ $\mathrm{mg} / \mathrm{l}, 1065.6 \pm 1383.8 \mathrm{mg} / \mathrm{l}$ and $2258 \pm 955.5 \mathrm{mg} / \mathrm{l}$ for Alphonso, Temidire and Ojoo respectively. The mean concentration of the control was $58.3 \pm 0.6 \mathrm{mg} / \mathrm{l}$. All these values were much higher than the control, indicating possible conta- 
mination from auto-mechanic activities. The concentrations of oil and grease in the study area were far above the WHO limits for water $(10-30 \mathrm{mg} / \mathrm{l})$. This calls for serious attention considering the toxicity of hydrocarbons which cause a range of human health issues such as liver and kidney diseases to high risk of cancer. These high results may not be unconnected with volume of engine and gear oil spilled during car servicing as well as the petrol spills that occur when washing some engine parts. The gradual occurrence over a period based on the years of existence of the workshops will have a likely impact on the groundwater quality within that environment. Study by Eljaiek-Urzola et al. [30] proposed the adoption of oil and grease as a "new water quality index parameter for the preservation of marine biota in tropical areas, since it is a typical pollutant found and measured in water bodies, causing damage to the aquatic environment".

\section{Heavy metals}

The concentrations of heavy metals in the groundwater samples in the study area varied per zone having mean concentrations above the permissible limits by WHO and SON (Cu: 1mg/l; Cr: $0.05 \mathrm{mg} / \mathrm{l}$; Cd: $0.003 \mathrm{mg} / \mathrm{l}$ and Pb: $0.01 \mathrm{mg} / \mathrm{l}$ ) with the exception of lead in Temidire and Ojoo zones. The results showed highest concentrations of these metals in Alphonso zone, the mean values being $\mathrm{Cu}: 2.5$ $\mathrm{mg} / \mathrm{l}, \mathrm{Cr}: 0.34 \mathrm{mg} / \mathrm{l}, \mathrm{Cd}: 0.01 \mathrm{mg} / \mathrm{l}$ and $\mathrm{Pb}: 10.5 \mathrm{mg} / \mathrm{l}$. Lead having the highest concentration. The mean concentrations of $\mathrm{Cu}$ were $2.5 \pm 2.06 \mathrm{mg} / \mathrm{l}, 0.03 \pm 0.01$ $\mathrm{mg} / \mathrm{l}$ and $0.03 \pm 0.01 \mathrm{mg} / \mathrm{l}$ for Alphonso, Temidire and Ojoo respectively. The concentration at Moniya (control site was) $1.46 \pm 0.01 \mathrm{mg} / \mathrm{l}$. The high concentration of $\mathrm{Cu}$ in this study if sustained over time, could cause health effects because copper poses potential health threats, such as liver and kidney damage if the exposure is long term [12] and gastrointestinal disease if short term exposure [31]. Another effect that could arise is the Wilson's disease. Some study showed that a link has been found between long term exposure to copper and decline of intelligence in young adolescents [32].

Lead was detected only in water samples from Alphonso with a mean value of $10.5 \pm 11.37 \mathrm{mg} / \mathrm{l}$. It was found absent in water samples from Temidire, Ojoo and the control site. Concentrations of $\mathrm{Pb}$ were higher than those observed in the study by Bala et al., [33]. Studies have shown that a concentration of $0.1 \mathrm{mg} / \mathrm{l}$ of $\mathrm{Pb}$ in water could lead to fetuses and children developing neurological disorders [34] [35]. Potential effects of $\mathrm{Pb}$ levels above the maximum guidelines have also been observed to cause kidney malfunctions and high blood pressure in adults [36]. The mean concentration for $\mathrm{Cd}(\mathrm{mg} / \mathrm{l})$ was $0.01 \pm 0.02,0.37 \pm 0.51$ and 0.64 \pm 0.79 in Alphonso, Temidire and Ojoo. Cadmium was not detected at the control site. The high concentration of cadmium is a major concern considering its carcinogenicity [37] as well as a long biological half-life [38] leading to chronic effects as a result of accumulation in the liver and renal cortex [39]. It can also cause kidney damage and produce severe health effects which originate from exposures to high concentrations and long-term exposures [38]. The mean concentrations of $\mathrm{Cr}$ were $0.34 \pm 0.28 \mathrm{mg} / \mathrm{l}, 0.37 \pm 0.13 \mathrm{mg} / \mathrm{l}$ and $0.31 \pm 0.3 \mathrm{mg} / \mathrm{l}$ for Alphonso, Temidire and Ojoo respectively. Chromium was not detected at con- 
trol site. Although chromium in its trivalent form is an essential nutrient, exposure to its hexavalent form in amounts above permissible limits is hazardous to health because it is carcinogenic. In addition to this, it could cause damage to liver, kidney circulatory organs and nerve tissues and cancer of the lungs [40]. Presence of heavy metals in high concentrations in groundwater sources around the informal auto-mobile mechanic workshops selected for this study could be associated with use of various materials containing metals and improper disposal of wastes. This corroborates Talabi, et al. [41] which indicated that release of chemicals whether incidentally or intentionally have the capacity to contaminate groundwater.

\subsection{Sanitary Inspection Score and Risk Assessment}

The inspection revealed that wells at locations 1, 7, 11, 12 and 19 had risk scores between 8 and 9 indicating that they were at high risk of contamination, locations $4,5,8,9,10,13,14,15$ and 17 had risk scores between 5 and 7 indicating intermediate risk of contamination while locations 2, 3, 6, 16, 18 and 20 had risk scores between 1 and 4 Locations 1, 7 and 19 had the highest risk of contamination while location 3 had the lowest risk of contamination (Table 2).

Figure 7 shows the classification of the level of risk around the 20 wells used in this study, while Table 3 details the sources and types of contaminants produced in the auto-mobile mechanic workshops. Overall, $25 \%$ of the water sources inspected were at high risk of contamination, $45 \%$ had medium risk while the remaining $30 \%$ had low risk of contamination. Based on WHO recommendation [20], the sanitary inspection of sources enabled us to identify deficiencies in the groundwater supply systems in the study area that could lead to contamination and pose a risk to the health of the consumers. The results of the sanitary inspections could contribute to water safety by guiding remedial actions that are required at each water source [42].

Table 2. Level of risk of groundwater sources around the mechanic workshops.

\begin{tabular}{cccc}
\hline Locations & Risk Score $\ldots / 13$ & Locations & Risk Score $\ldots / 13$ \\
\hline W1 & 9 & W11 & 8 \\
W2 & 2 & W12 & 6 \\
W3 & 1 & W13 & 5 \\
W4 & 6 & W14 & 5 \\
W5 & 6 & W15 & 2 \\
W6 & 3 & W16 & 5 \\
W7 & 9 & W11 & 5 \\
W8 & 5 & W18 & 3 \\
W9 & 7 & W19 & 5 \\
W10 & 5 & W20 & 2 \\
\hline
\end{tabular}

Key: No risk $=0$, Low $=1-3$; Intermediate risk $=4-7$, High risk= $8-10$; Extremely high risk $=>10$. 
Table 3. Summary of Implications of auto-mobile mechanic workshop activities.

\begin{tabular}{cc}
\hline Contaminant & Sources from the Auto-mobile workshops \\
\hline $\begin{array}{c}\text { Engine oil } \\
\text { Grease }\end{array}$ & Waste engine oils drained from vehicles or used for lubrication of body parts \\
Gear oil & Lubricants \\
Carbide & Waste gear lubricant oils \\
Lead & Wielding \\
Cadmium & Petrol, body parts, acid waste from battery, used copper wire \\
Chromium & Batteries, painting, petrol \\
Copper & Panel beating, car body scrapping and painting
\end{tabular}

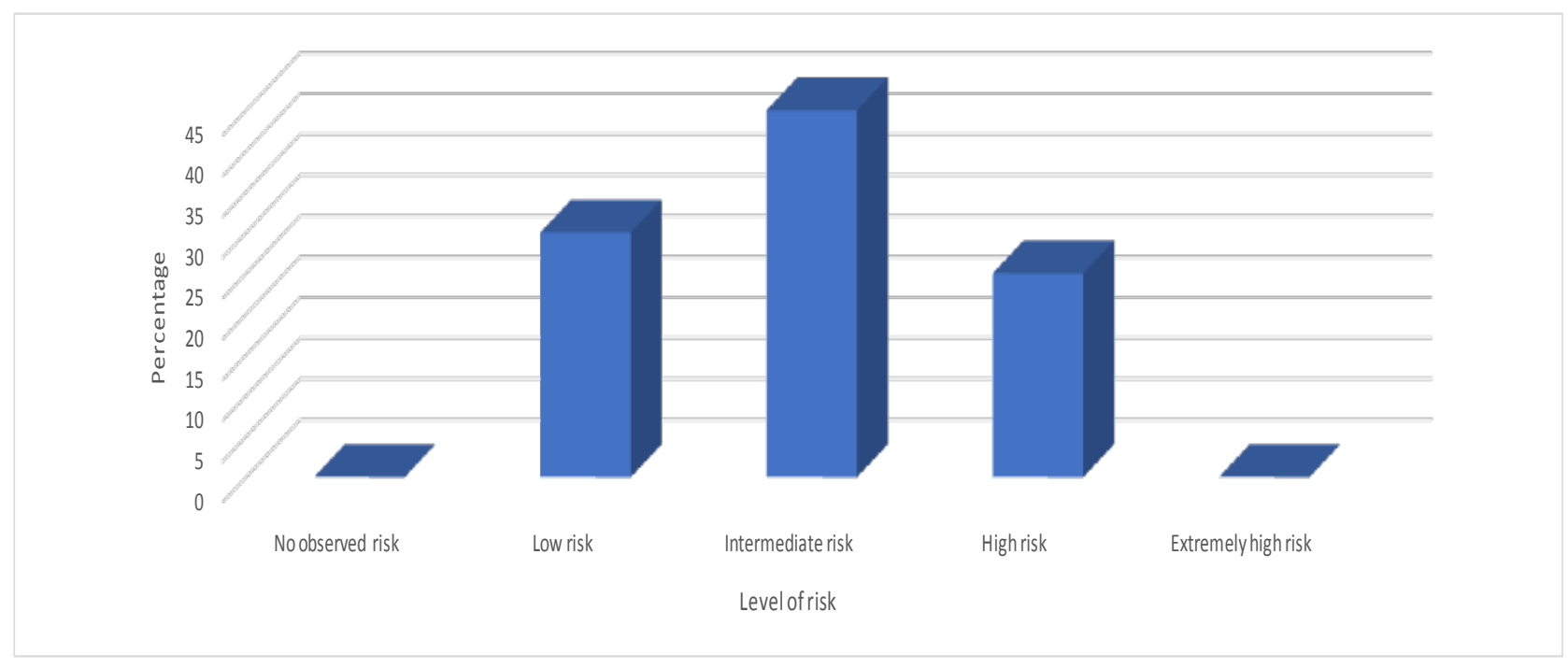

Figure 7. Classification of the level of risk of groundwater sources around the mechanic workshops.

\section{Conclusion}

The high concentration of heavy metals $(\mathrm{Pb}, \mathrm{Cd}, \mathrm{Cr}$ and $\mathrm{Cu})$ and the oil and grease content show that the groundwater in the study area is contaminated and the water quality compromised. This is not unassociated with the activities, within these informal auto-mobile mechanic workshops which include vehicle engine servicing, panel beating, body scrapping, battery charging and painting of the auto-mobiles. Sanitary inspection of water sources, therefore, provides a quick risk assessment that enables remedial measures to be put in place in the absence of water quality results. Contamination of the groundwater is a major threat to the health of the consumers hence, there is a need for enforcement of environmental regulations related to auto-mobile service operations as well as groundwater monitoring around areas with similar activities in Ibadan metropolis and other parts of Nigeria considering the uncontrolled proliferation of these informal automobile workshops all over the country in recent years. The outcome of our study provides background information for policy formulation in this direction. 


\section{Conflicts of Interest}

The authors declare no conflicts of interest regarding the publication of this paper.

\section{References}

[1] Ajayi, A.B. and Dosumu, O.O. (2002) Environmental Hazards of Importing Used Vehicles into Nigeria. Proceedings of International Symposium on Environmental Pollution Control and Waste Management, Tunis, 7-10 January 2002, 521-532.

[2] Anoliefo, G.O. and Edegbai, B.O. (2000) Effect of Spent Engine Oil as a Soil Contaminant on The Growth of Two Eggplant Species Solanum melongena (L) and S. incanum (L). Journal of Agriculture Forestry and Fisheries, 1, 21-25.

[3] Adelekan, B.A. and Abegunde, K.D. (2011) Heavy Metals Contamination of Soil and Groundwater at Auto-Mobile Mechanic Villages in Ibadan Nigeria. International Journal of the Physical Sciences, 6, 1045-1058.

[4] Scanlon, B.R., Reedy, R.C., David, A., Tonestromw, S., Prudicz, D.E. and Dennehy, K.F. (2005) Impact of Land Use and Land Cover Change on Groundwater Recharge and Quality in the Southwestern US. Global Change Biology, 11, 1577-1593. https://doi.org/10.1111/j.1365-2486.2005.01026.x

[5] WHO (World Health Organization) (2006) Protecting Groundwater for Health. In: Schmoll, O. and Howard, G., Eds., Managing the Quality of Drinking-Water Sources, IWA Publishing, London, $678 \mathrm{p}$.

[6] Longe, E.O. and Balogun, M.R. (2010) Groundwater Quality Assessment near a Municipal Landfill, Lagos, Nigeria. Research Journal of Applied Science, Engineering and Technology, 2, 39-44

[7] Iwegbue, C.M.A. (2007) Metal Fractionation in Soil Profiles at Automobile Mechanic Waste Dumps. Waste Management Resources, 25, 585-593. https://doi.org/10.1177/0734242X07080761

[8] Ipeaiyeda, A.R. and Dawodu, M. (2008) Heavy Metals Contamination of Topsoil and Dispersion in the Vicinities of Reclaimed. Bulletin of the Chemical Society of Ethiopia, 22, 339-348. https://doi.org/10.4314/bcse.v22i3.61205

[9] Ilemobayo, O. and Kolade, I.E. (2008) Profile of Heavy Metals from Automobile Workshops in Akure, Nigerian. Journal of Environmental Science and Technology, 1, 19-26.

[10] Nwachukwu, M.A., Feng H. and Achilike, K. (2010) Integrated Study for Automobile Will Wastes Management and Environmentally Friendly Mechanic Villages in the River Basin, Nigeria. African Journal of Environmental Science and Technology, 4, 234-249.

[11] Abdulaziz, B.A. and Muhammad, H. (1997) Role of Epidemiological Studies in Determining Environmental Impact on Health in Saudi Arabia. Book of Abstract for the Development and Environmental Impact Conference, Riyadh, Saudi Arabia, 196.

[12] Lenntech, B.V. (2011) Heavy Metals. http://www.lenntech.com/processes/heavy/heavy-metals/heavy-metals.html

[13] Ray, M. (1990) Accumulation of Heavy Metals in Plants Grown in Industrial Areas. Indian Biologists XXII, 2, 33-38.

[14] IARC (International Agency for Research on Cancer) (1990) Chromium, Nickel and Welding. International Agency for Research on Cancer, Lyon.

[15] Anetor, J.I. and Adeniyi, F.A.A. (1998) Decreased Immune Status in Nigerian 
Workers Occupationally Exposed to Lead. African Journal of Medicine and Medical Sciences, 28, 169-172.

[16] Ajibola, B.H., Odunfa, K.M. and Adeaga, O.A. (2017) Numerical Simulation of Underground Flow in Aquifer in Akinyele Local Government Area, Oyo State, Nigeria. International Journal of Engineering Innovation \& Research, 6, 217-223.

[17] Clescerl, L.S., Greenberg, A.E. and Eaton, A.D. (1999) Standard Methods for the Examination of Water and Wastewater. 20th Edition, American Public Health Association, Washington, DC.

[18] WHO (World Health Organization) (2003) Guidelines for Drinking Water Quality. (WHO/SDE/WSH 03.04).

http://www.who.int/water_sanitation_health/publications/2011/9789241548151_an nex.pdf

[19] Nigerian Standard for Drinking Water Quality (NSDWQ) (2015) Nigerian Industrial Standard NIS 554, Standard Organization of Nigeria.

https://africacheck.org/wp-content/uploads/2018/06/Nigerian-Standard-for-Drinki ng-Water-Quality-NIS-554-2015.pdf

[20] WHO (1997)ן Guidelines for Drinking-Water Quality. Surveillance and Control of Community Supplies. 2nd Edition, World Health Organization, Geneva. https://apps.who.int/iris/bitstream/handle/10665/42002/9241545038.pdf?sequence $=1$ \&isAllowed $=\mathrm{y}$

[21] Sarath Prasanth, S.V., Magesh N.S., Jitheshlal, K.V., Chandrasekar, N. and Gangadhar, K. (2012) Evaluation of Groundwater Quality and Its Suitability for Drinking and Agricultural Use in the Coastal Stretch of Alappuzha District, Kerala, India. Applied Water Science, 2, 165-175. https://doi.org/10.1007/s13201-012-0042-5

[22] Prati, L., Pavanello, R. and Pesarin, F. (1971) Assessment of Surface Water Quality by Single Index Pollution. Water Research, 5, 741-751. https://doi.org/10.1016/0043-1354(71)90097-2

[23] DiValentino, A. (2019) Health Effects of $\mathrm{pH}$ on Drinking Water. http://www.livestrong.com/article/214475-health-effects-of-ph-on-drinking-water/

[24] Semikolennykh, A.A., Rahleeva, A.A. and Poputnikova, T.B. (2012) Spent Carbide Waste Retains Toxicitylong Term after Disposal in Caves and Mines. Acta Carsologica, 41, 129-137. https://doi.org/10.3986/ac.v41i1.53

[25] Langeneggar, O. (1990) Groundwater Quality in Rural Areas of Western African. UNDP Project 81, 26, 10 .

[26] Ololade, I.A., Adewunmi, A., Ologundudu, A. and Adeleye, A. (2009) Effects of Household Wastes on Surface and Underground Waters. International Journal of Physical Sciences, 4, 22-29.

[27] Alao, O., Arojojoye, O., Ogunlaja, O. and Famuyiwa, A. (2010) Impact Assessment of Brewery Effluent on Water Quality in Majawe, Ibadan. Southwestern Nigeria. Researcher, 2, 21-28.

[28] Nebo, C.U., Udom, G.J. and Ehirim, C.N. (2018). Contaminant Impact Assessment of Automobile Mechanic Workshop on Soil and Groundwater Resource in Port Harcourt, Nigeria. International journal of Science Inventions Today, 7, 451-463.

[29] Adewoyin, O.A., Hassan, A.T. and Aladesida, A.A. (2013) The Impacts of Auto-Mechanic Workshops on Soil and Groundwater in Ibadan Metropolis. African Journal of Environmental Science and Technology, 7, 891-898.

[30] Eljaiek-Urzola, M., Romero-Sierra, N., Segrera-Cabarcas, L., Valdelamar-Martínez, 
D. and Quiñones-Bolaños, É. (2019) Oil and Grease as a Water Quality Index Parameter for the Conservation of Marine Biota. Water, 11, 856-875. https://doi.org/10.3390/w11040856

[31] WQA, Water Quality Association (2015) Technical Application Bulletin. Copper: Recognized Treatment Techniques for Meeting Drinking Water Regulations for the Reduction of Copper from Drinking Water Supplies Using Point-of-Use/Point-of-Entry Devices and Systems.

https://www.wqa.org/Portals/0/Technical/Technical\%20Fact\%20Sheets/2015_Copp er.pdf

[32] Lenntech, W.T. (2009) Chemical Properties, Health and Environmental Effects of Copper. Lenntech Water Treatment and Purification Holding B.V. https://www.lenntech.com/periodic/elements/cu.htm

[33] Bala, M., Shehu, R.A. and Lawal, M. (2008) Determination of the Level of Some Heavy Metals in Water Collected from Two Pollution-Prone Irrigation Areas around Kano Metopolis. Bayero Journal of Pure and Applied Sciences, 1, 36-38. https://doi.org/10.4314/bajopas.v1i1.57511

[34] Fatoki, O.S., Lujiza, N. and Ogunfowokan, O.A. (2002) Trace Metal Pollution in Umtata River. Water $S A, 28,183-190$. https://doi.org/10.4314/wsa.v28i2.5160

[35] EPHA, European Public Health Alliance (2009) Air, Water Pollution and Health Effects.

https://epha.org/category/website-transfer/attic/old-environment/air-water-pollutio n-and-health-effects/

[36] Zietz, B.P., Lap, J. and Suchenwirth, R. (2007) Assessment and Management of Tap Water Lead Contamination in Lower Saxon, Germany. International Journal of Environmental Health Research, 17, 407-418. https://doi.org/10.1080/09603120701628719

[37] Lauwerys, R.R. (1979) Health Effects of Cadmium. In: Di Ferrante, E., Ed., Trace Metals. Exposure and Health Effects, Pergamon Press, Oxford, England, 43-64.

[38] Orisakwe, O.E., Igwilo, I.O., Afonne, O.J., Ugwuona Maduabuchi, J.-M., Obi, E. and Nduka, J.C. (2006) Heavy Metal Hazards of Sachet Water in Nigeria. Archives of Environmental and Occupational Health, 61, 209-213. https://doi.org/10.3200/AEOH.61.5.209-213

[39] Hammer Sr., M.J. and. Hammer Jr., M.J. (2004) Water Quality. In: Hammer, M.J. and Hammer, Jr., M.J., Eds., Water and Wastewater Technology, 5th Edition, Pearson, London, 139-159.

[40] OSHA (2011) Toxic Metals. Occupational Safety and Health Administration Newsletter, US Department of Labour. http://www.osha.gov/SLTC/metalsheavy/index.html

[41] Talabi, A.O. and Kayode, T.J. (2019) Groundwater Pollution and Remediation. Journal of Water Resource and Protection, 11, 1-19. https://doi.org/10.4236/jwarp.2019.111001

[42] Kelly, E.R., Cronk, R., Kumpel, E., Howard, G. and Bartram, J. (2018) How We Assess Water Safety: A Critical Review of Sanitary Inspection and Water Quality Analysis. Science of the Total Environment, 718, Article ID: 137237. https://doi.org/10.1016/j.scitotenv.2020.137237 


\section{List of Abbreviations}

APHA: American Public Health Association

Cd: Cadmium

Cox: Oxides of Carbon

Cr: Chromium

$\mathrm{Cu}$ : Copper

EC: Electrical Conductivity

IARC: International Agency for Research on Cancer

NISDQW: Nigerian Industrial Standard for Drinking Water Quality

NOx: Oxides of Nitrogen

$\mathrm{Pb}$ : Lead

$\mathrm{pH}$ : Symbol for hydrogen ion concentration

SON: Standards Organization of Nigeria

Sox: Oxides of Sulphur

TDS: Total Dissolved Solids

VOCs: Volatile Organic Compounds

PAHs: Poly-Aromatic Hydrocarbons 